\title{
変動する聴力を示した再発性多発性軟骨炎例
}

\author{
兵行義・平井 滋夫 ·原田保
}

\section{A Case of Relapsing Polychondritis}

\author{
Yukiyoshi Hyo, Shigeo Hirai and Tamotsu Harada \\ (Kawasaki Medical School)
}

\begin{abstract}
Relapsing polychondritis (RP) is an uncommon inflammatory disease that mainly affects cartilage tissue in the auricles, nose, and respiratory tract. A 63-year-old man was admitted to our hospital with left hearing loss and tinnitus. His auricle had degenerated, but the tympanic membrane remained normal. His hearing level gradually decreased to $90 \mathrm{~dB}$ degree. Treatment with a steroid hormone (hydrocortisone) was initiated but the hearing level showed only slight improvement after a few weeks. Three months later, he was hospitalized with right hearing loss and was treated with hydrocortisone at the same dose. However, hearing level continued to decrease. Thereafter, he was treated with $1000 \mathrm{mg}$ of methylprednisolone for three days. After one month, slight improvement was seen.

We suggest that hearing loss in RP should be with treated with pulse therapy using a steroid hormone, and that the patient should be followed for a prolonged period.
\end{abstract}

Key words : relapsing polychondritis, hearing loss, steroid

はじめに

再発性多発性軟骨炎 (relapsing polychondritis ; 以下 RP と略す）は全身の軟骨およびムコ多糖類を多く含む組織 が系統的に侵される全身性炎症性疾患である. 1923 年に 初めて Jaksch-Wartenhorst が報告1) し，欧米では 500 例 を超える報告2)がなされている．本邦においては 100 例 程度の報告3) しかないまれな疾患である。今回われわれ は聴力変動を示し, ステロイドパルス療法が聴力改善の 契機になり,その後も変動する聴力像を示した RP の 1 例を経験したので若干の文献的考察を加えて報告する.

\section{症 例}

症例 : 63 歳, 男性.

主訴：左難聴, 耳鳴.

家族歷：特記すべき事項なし.

既往歴：特記事項なし.

現病歴: 平成 7 年加ら当院皮虐科にて RP と診断され，
その後経過観察されていた.

平成 9 年 4 月頃, 左向き頭位でめまい感が増強するた めに紹介入院となった. 来院時の耳介所見（図 $1 \mathrm{~A} ）$ と純 音聴力検查（図 $2 \mathrm{~A}$ ）を示す. 耳介全体に発赤を伴い, 聴 力検查では特に難聴は認められなかった。 入院時, 右向 き水平性眼振が認められ, 温度眼振検査にて左反応低下 を示した。徐々に症状軽減を示したために RP に伴う内 耳障害と診断し, 症状回復したために退院となり, 外来 にて経過観察していた。

平成 15 年 3 月 10 日, 胃癌の内視鏡的切除の目的で消 化器内科に入院中であったが, 左難聴, 左耳鳴が出現し たため当科受診となった。 めまいの訴えはなかった.

来院時所見: 両耳介の変形を認め, 非常に柔らかい耳 介であったが (図 $1 \mathrm{~B})$, 両側外耳道, 鼓膜は正常であっ た。その他, 鼻・咽喉には異常所見は認めなかった。

検查成績：純音聴力検查（4 分法）は右 $26.3 \mathrm{~dB}$, 左 $90.0 \mathrm{~dB}$ ) であった (図 $2 \mathrm{~B}$ ). またティンパノグラムは両 


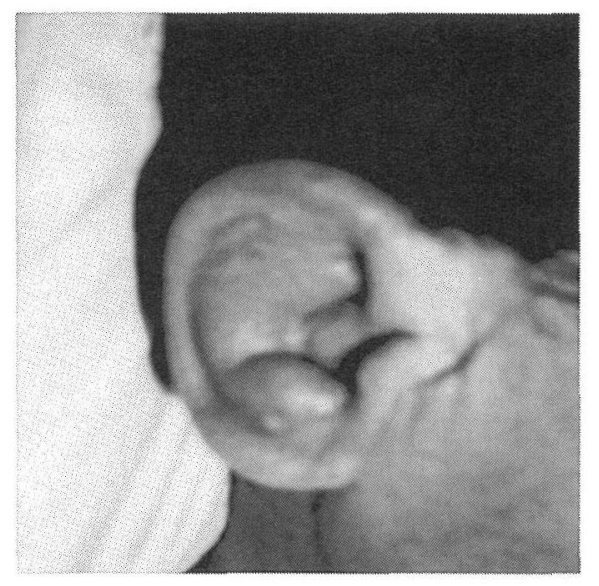

A

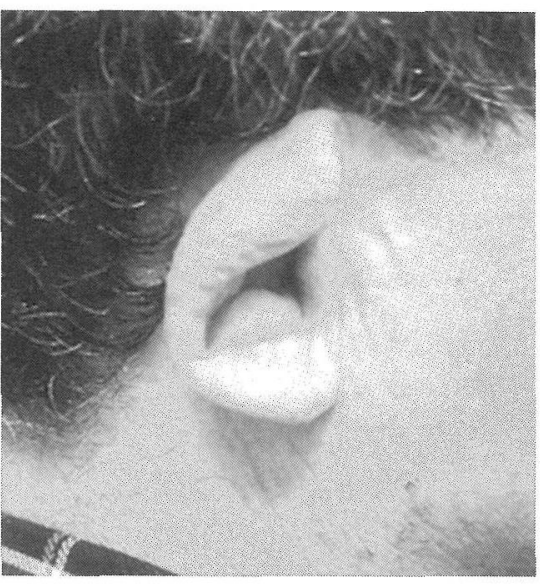

B

図 1 耳介所見

A : 平成 9 年 4 月

B : 平成 15 年 3 月 平成 9 年時に比べ耳介变形が著明。

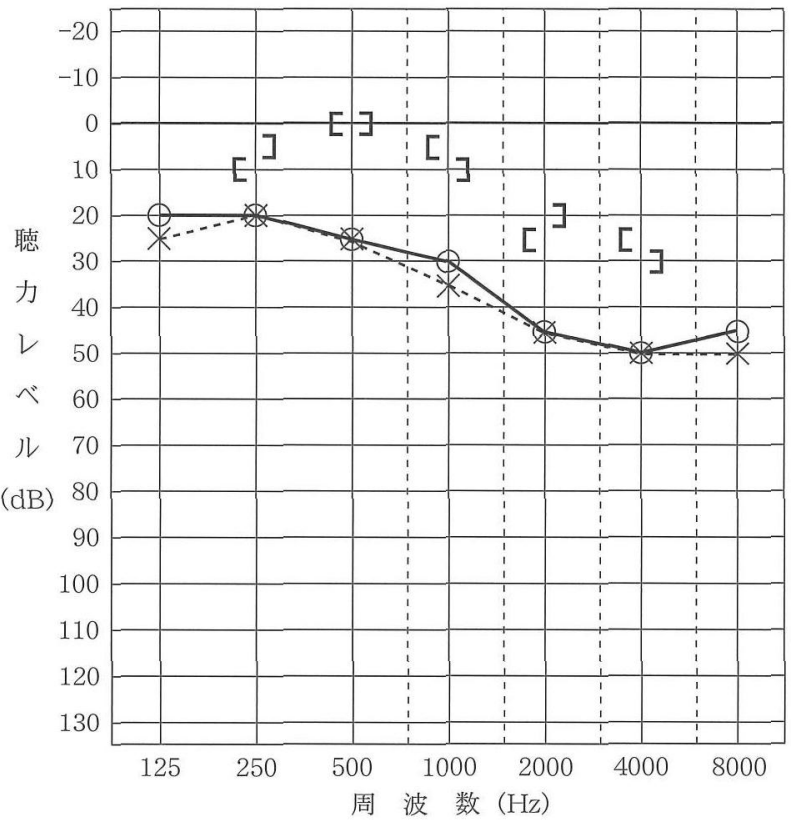

A

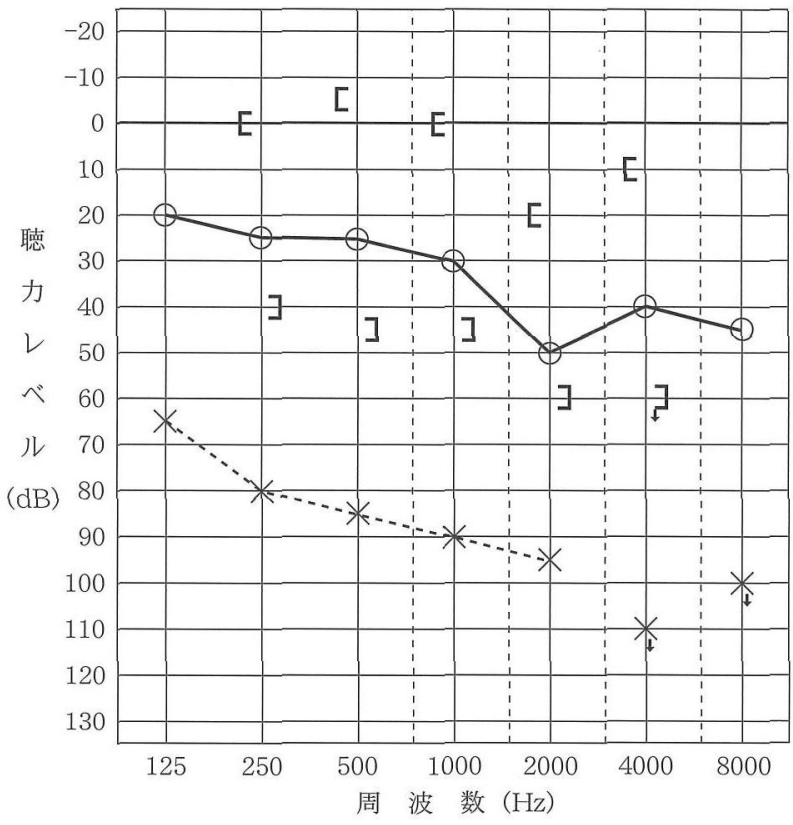

B

図 2 聴力検查所見 (A：平成 9 年 4 月, B : 平成 15 年 3 月)

側とも A 型であった。末梢血, 生化学検查に変化は認め なかった。

経過 : 左側の聴力低下は自己免疫疾患 (RP) に伴う急 性感音難聴と考え，ヒドロコルチゾン漸減療法（500 mg 3 日間， $300 \mathrm{mg} 3$ 日間， $100 \mathrm{mg} 3$ 日間）を開始した。ヒ
ドロコルチゾン漸減療法 1 クール終了時では聴力レベル は 4 分法で右 $18.8 \mathrm{~dB}$ ，左 $97.5 \mathrm{~dB}$ とほとんど变化がな く, 消化器内科を 4 月 3 日経過良好のために退院し, 外 来にて定期的経過観察をしていた.1 月月後外来受診時に は 4 分法にて右 $23.8 \mathrm{~dB}$, 左 $90.0 \mathrm{~dB}$ であり, やや改善を 


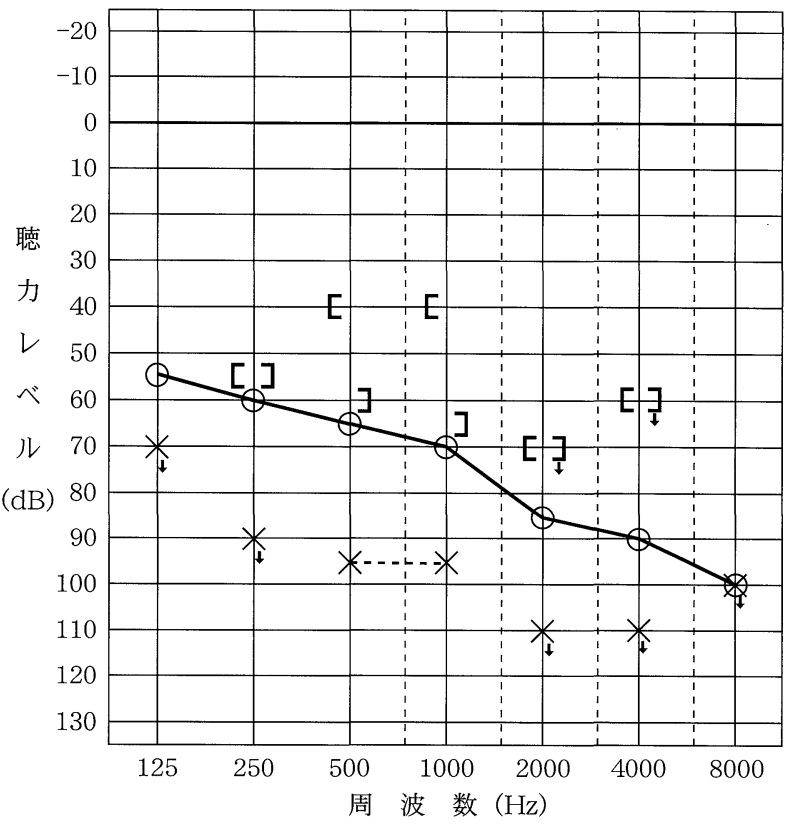

図 3 平成 15 年 6 月 3 日 聴力検査所見

示していた．本人の自覚症状では聴力の回復を示してい た.

6 月 2 日, 突然の右難聴を訴え外来受診し, 純音聴力 検查にて 4 分法右 $72.5 \mathrm{~dB}$, 左 $100.0 \mathrm{~dB}$ と右耳の聴力低 下を認めた（図 3)。左耳も $500 \mathrm{~Hz}, 1000 \mathrm{~Hz}$ を除いてス ケールアウトとなっていた. ティンパノグラムは両側と も $\mathrm{A}$ 型であった. 本人の希望もあり, 前回と同用量にて ヒドロコルチゾン漸減療法を施行した。 治療終了時に聴 力検査 4 分法は右 $96.3 \mathrm{~dB}$, 左 $108.8 \mathrm{~dB}$ とさらに増悪を 認めた（図 4).

6 月 21 日, RP の症状である気管支狭窄音, 血液検查 にて赤沈 $77 \mathrm{~mm}$ の高值を示したために，RP の全身的症 状の悪化の可能性があるため, 腎臓リウマチ内科に転科 となった，気管支狭窄音は気管支断層写真にて前回と变 化はなかったが，メチルプレドニゾロン $1000 \mathrm{mg} 3$ 日間, 2 クールのステロイドパルス療法を開始した. その後赤 沈 $8 \mathrm{~mm}$ と良好になったため, 7 月 18 日退院となった。 その際聴力は 4 分法で右 $70.0 \mathrm{~dB}$, 左 $87.5 \mathrm{~dB}$ とかなりの 改善を示していた.

また聴力の変化の可能性があるものの本人, 家族の強 い要望により補聴器を装着した。 その結果 ADL (Activity of daily life）は以前よりも向上した.

その後, 外来に定期的に受診した際聴力検査を施行し

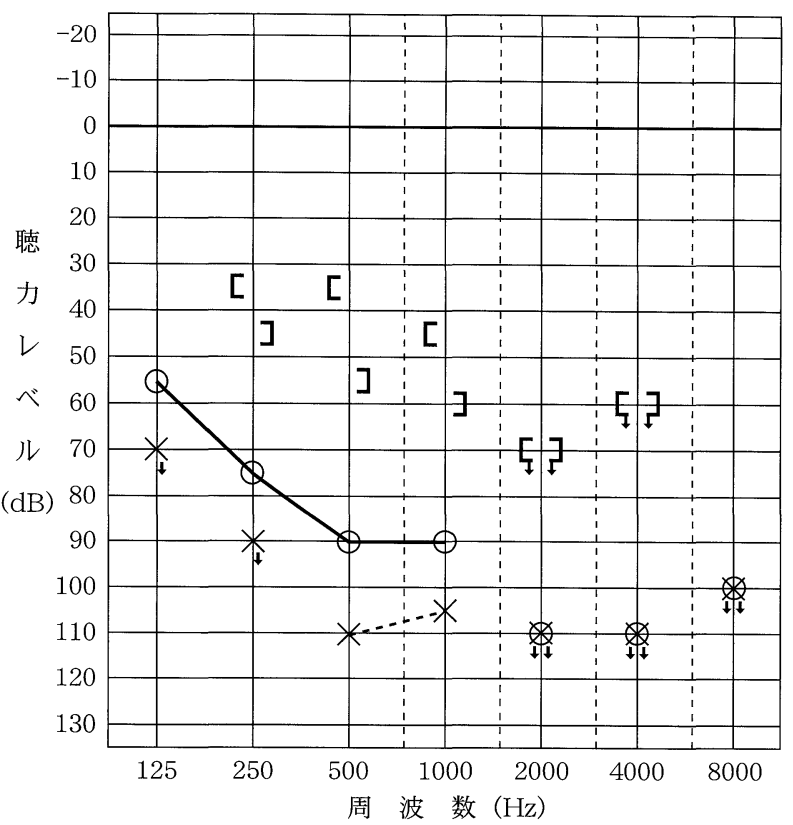

図 4 平成 15 年 6 月 11 日 聴力検査所見（ヒドロコルチゾン 漸減療法終了時)

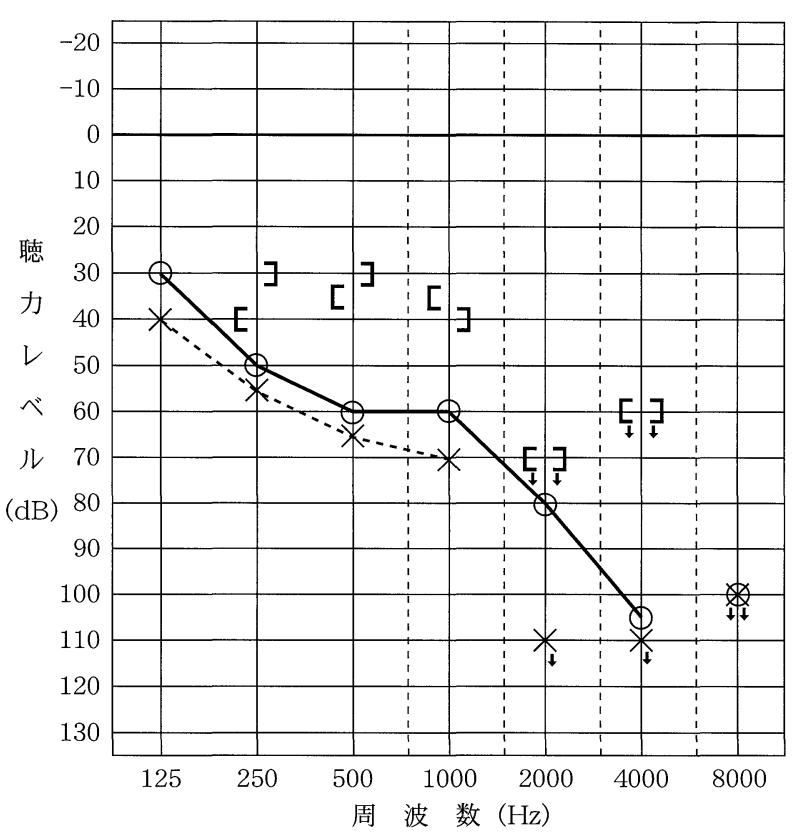

図 5 平成 16 年 2 月 20 日 聴力検査所見（外来経過観察時）

た. 4 分法で右 $65.0 \mathrm{~dB}$, 左 $80.0 \mathrm{~dB}$ と左右ともに改善, 悪化と聴力の変動を示した（図 5).

治療経過とその後の聴力検查 4 分法の推移を図 6 亿示 す。ヒドロコルチゾンの漸減療法ではほとんど変化がな 


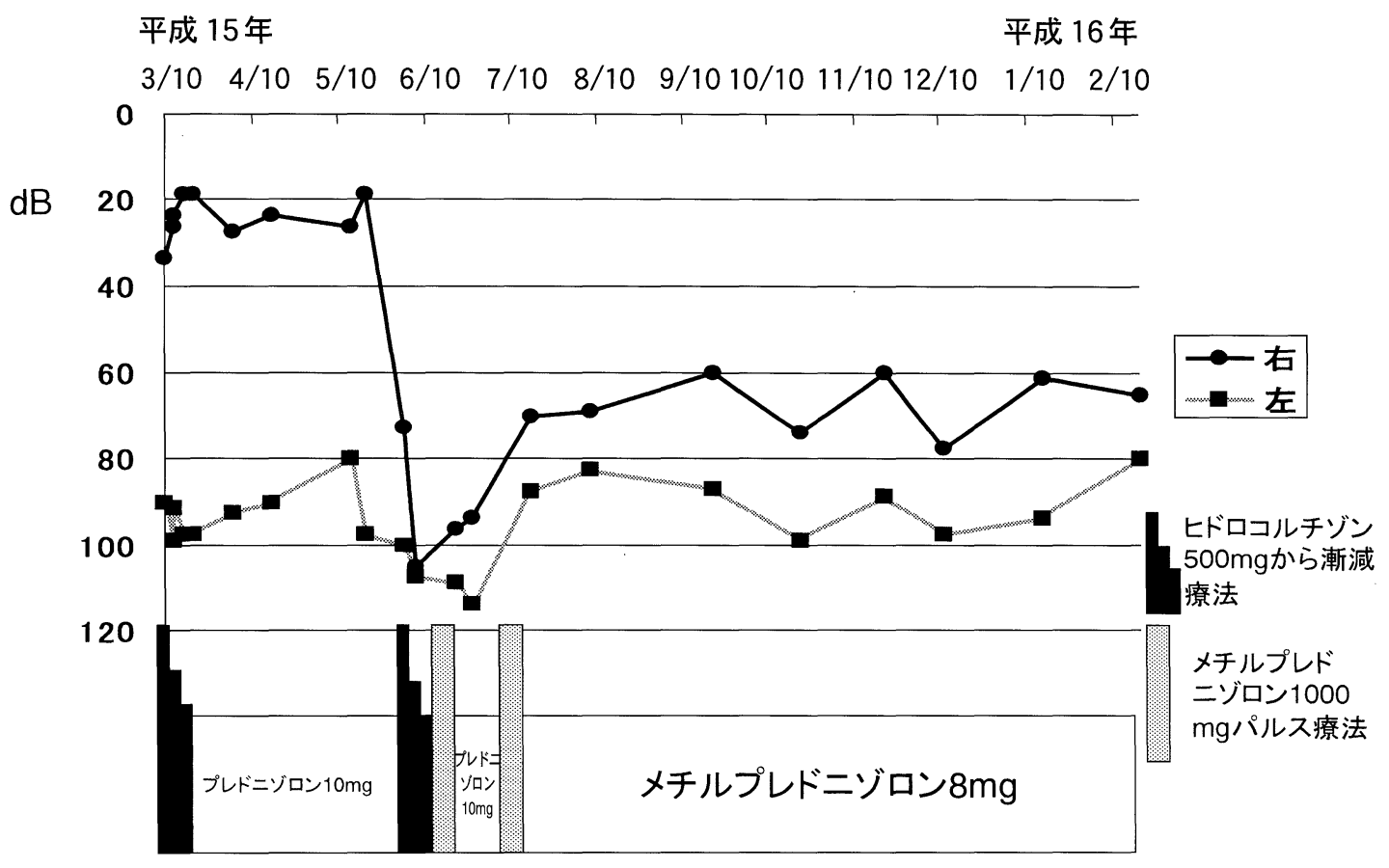

図 6 聴力の変動と治療経過

く, メチルプレドニゾロンのパルス療法が聴力回復の契 機になっている.

\section{考察}

再発性多発性軟骨炎（RP）は 1923 年に Jaksch-Wartenhost $^{1)}$ が報告して以来, 比較的まれな疾患とされてきた. 本邦では 1953 年に後藤 ${ }^{4)}$ が特発性耳鼻喉頭軟骨膜炎と 報告したのが最初である. 1976 年に McAdam ら ${ }^{5)}$ が診断 基準（表 1）を報告し，その後 Damiani ら ${ }^{6)} に よ り$ 改定 された．診断基準から(2)，(4)以外は耳鼻咽喉科領域であ る. 本症例の場合は当科初診ではなかったものの, 患者 の多くが耳鼻咽喉科を受診する可能性はきわめて高いこ とが推測できる。とのなかでも内耳障害は McAdam ら5) によれば 45. 9\%であり, 本邦の報告では角田ら ${ }^{3)}$ は 39.0 $\%$ ，中丸ら ${ }^{7)} 20.0 \%$ と報告している.

本疾患の原因は明確ではないが，自己免疫性が有力で あり, II 型, IV 型, VI 型コラーダン, マトリリン I に対 する自己抗体が発症に関与することが指摘されてい る8)9). また内耳における II 型コラーゲンの局在は蝸牛骨 包内側面, らせん靭帯, 蓋膜, 骨らせん板, 血管条, 基 底板，三半規管膜迷路，内リンパ管，および内リンパ囊 とされている10111).
表 1 再発性多発性軟骨炎診断基準

再発性多発性軟骨炎（1976 McAdam）

(1)反復性の両側耳介軟骨炎

(2)非びらん性関節炎

(3)鼻軟骨炎

(4)眼科症状

(5)喉頭ないし気管軟骨炎

(6)蝸牛ないし前庭障害による聴力障害, 耳鳴, めまい

以上 6 項目中少なくとも 3 項目と病理所見

Damiani による修正基準（1979 Damiani）

（1）上記 3 項目以上あれば病理所見は不要

(2) 上記 1 項目と病理所見

（3）解剖学的に異なる 2 所以上の軟骨炎でステロイド 薬, Dapson に反応するもの

このように内耳の II 型コラーゲンの局在部位にて, 自 己免疫反応を惹起し, 難聴をもたらしたと考えられる.

本症例ではメチルプレドニゾロン（ヒドロコルチゾン の抗炎症作用は 5 倍の力価, 抗免疫作用は 10 倍）投与 後, $20 \mathrm{~dB}$ ほどの聴力改善は右耳では約 1 力, また左耳 では 5 月を要している.つまり今回ヒドロコルチゾン の投与の際は著明回復を示さず，メチルプレドニゾロン パルスの投与を契機に左側も5力月経過した後にも回復 
の傾向を示している．これらのことから II 型コラーゲン を多く有する血管条が障害されたのではないかとわれわ れは考えた。

さらに, Cody ら ${ }^{12)}$ は 40 例の RP に対して 11 例に難聴 があり，そのうち 8 例に感音難聴，3 例に伝音難聴を認 めたと報告しているが，今回の症例においても難聴出現 時には気導骨導差が存在しており, 聴力が回復するに従 い，この差も減少を示した. Cody ら ${ }^{12)}$ は RP の病巣が耳 管軟骨部にも存在しているためと報告をしているが，わ れわれはそれだけではこのような気導骨導差は存在しな いためにあぶみ骨を中心とする耳小骨関節内のコラーゲ ンに対する免疫反応が惹起されたと考えた。

西山 ${ }^{13)}$ は, 聴力および平衡機能障害を発症している 18 例について両側は 11 例, 右側 3 例, 左側が 3 例, 不詳は 1 例と示している．本症例は RP の聴力障害のなかで最 も多い両側型に属している.

$\mathrm{RP}$ では一側耳聴力が壟のまま固定しているにもかか わらず, 対側耳聴力が経過中に変動したといら報告 ${ }^{14) ~ 16) ~}$ は多くあるが，本症例のように固定と思われた一側耳聴 力もメチルプレドニゾロンパルス療法を契機に改善した という報告は皆無であった。

RP に伴う難聴症例にはヒドロコルチゾンの無効な症 例においても，高力価のステロイドホルモンを大量用い れば聾レベルの聴力から脱することが可能であると考え た。 また，ステロイド大量療法の速効性はすでに報告さ れている17) 20). たしかに本症例でもメチルプレドニゾ ロンパルス療法直後には即効性を示した，それに加え変 動しながら長期間における聴力回復を示した点が典型例 とは異なり興味深い。

\section{まとめ}

1）われわれは両耳聴力の変動する RP の1例を経験し た.

2）高力価のステロイド投与が契機になり聴力改善傾 向を示した.

3）RP は長期的な聴力経過観察が必要と思われた。

\section{参考文献}

1) Jaksch-Wartenhorst $R:$ Polychondropathia. Wien Arch Inn Med $6: 93 \sim 100,1923$.

2) Eng J and Sabanathan S : Airway complications in relapsing polychondritis. Ann Thorac Surg $51: 686 \sim 692,1991$.

3）角田篤信, 荒木伸彦, 松井 都, 他：声門下狭窄にて発症
した再発性軟骨炎の 1 例. 日気食会報 42:497〜 502, 1991.

4) 後藤紀男：特発性耳鼻喉頭軟骨膜炎の 1 例. 日耳鼻 56 ： 492, 1953.

5) McAdam LP, O'Hanlan MA, Bluestone R, et al. : Relapsing polychondritis: prospective study of 23 patients and a review of the literature. Medicine (Baltimore) $55: 193 \sim 215,1976$.

6) Damiani JM and Levine HL : Relapsing polychondritis: report of ten cases. Laryngoscope $89: 929 \sim 946,1979$.

7) 中丸有爾, 福田 諭, 関口四郎, 他: 当科における relapsing polychondritis の治療経験. 耳鼻免疫アレルギー 19: 194 195, 2000.

8) Foidart JM, Abe S, Martin GR, et al. : Antibodies to type II collagen in relapsing polychondritis. N Engl J Med $299: 1203 \sim$ 1207,1978

9) Hansson AS and Holmdahl R : Cartilage-specific autoimmunity in animal models and clinical aspects in patients: focus on relapsing polycondritis. Arthritis Res $4: 296 \sim 301,2002$.

10) Yoo TJ, Tomoda K, Stuart JM, et al. : Type II collagen-induced autoimmune sensorineural hearing loss and vestibular dysfunction in rats. Ann Otol Rhinol Laryngol $92: 267 \sim 271$, 1983.

11）友田幸一：Type II collagen の中耳及び内耳における分布形 態一免疫組織化学的観察一. Ear Res Jpn 15: $199 \sim 202$, 1982.

12) Cody DT and Sones DA : Relapsing polychondritis: audiovestular manifestations. Laryngscope 81:1208 1222, 1971.

13）西山康之:めまい症状で発症した Relapsing polychondritis の 1 例. Equilibrium Res $51: 348 \sim 355,1992$.

14）松浦寛司, 東野哲也, 牛迫泰明, 他：興味ある聴力変動を 示した Relapsing polychondritis の 1 例. 耳鼻 $36: 1189 \sim$ 1194, 1990.

15）西田 功, 工田昌也, 田頭宣治：変動する聴力を示した Relapsing polychondritis $の 1$ 例. 耳鼻臨床 補 $72: 179 \sim 186$, 1994.

16）樋口仁美, 坂田俊文, 菅村真由美, 他 : 内耳障害が先行し た再発性多発性軟骨炎の 1 症例. 耳喉頭頸 $76: 143 \sim 147$, 2004.

17) Homma S, Matsumoto T, Abe H, et al. : Relapsing polychondritis: pathological and immunological findings in an autopsy case. Acta Pathol Jpn $34: 1137 \sim 1146,1984$.

18）鈴木光子, 内田和仁, 長野正裕: 頑固な肋軟骨痛で発症し, 高度な気管狭窄症状を示した反復性多発性軟骨炎 (Relapsing polychondritis) の 1 例一本邦 53 例の文献的考察 一. 胸疾 $21: 665 \sim 671,1983$.

19）荻野 敏, 松永 亨, 大川内一郎, 他: 反復性多発性軟骨 炎の 2 症例. 耳喉 $59: 635 \sim 639,1987$.

20）出口啓伊子, 大矢良人, 荻野 敏, 他 : Relapsing polychondritis の 1 例. 耳鼻臨床 $80: 1505 \sim 1513 ， 1987$.

原稿受付 : 平成 16 年 4 月 1 日 原稿採択 : 平成 16 年 9 月 1 日 別刷請求先 : 兵 行義 干701-0192 倉敷市松島577 川崎医科大学耳鼻咽喉科学教室 